\title{
URGENSI MANAJEMEN SUMBER DAYA MANUSIA DALAM ERA OTONOMI DAERAH
}

\author{
OLEH \\ KAMALUDDIN \\ Program Studi Administrasi Negara, Universitas Muhammadiyah Sorong \\ Email : kamaluddinr67@gmail.com
}

\begin{abstract}
ABSTRAKSI
Tulisan terinspirasi oleh makalah Purwo Santoso "Merajuk Indonesia dalam Sinergi Kedaerahan" dimana dalam tulisan terkandung banyak kritikan dan pertanyaan kepada para desainer yang menjadi arsitek ke-Indonesian kita? Dengan menggunakan beberapa asumsi koleganya seperti Corneles Lay dan Pratikno yang secara tegas menjelaskan bahwa seperti proses penataan daerah, tidak bisa difahami sekedar sebagai proses teknokratis, penataan daerah memberi konsekuensi dan pertarungan politis, termasuk didalamnya pertarungan dalam menentukan tujuan atau arahnya. Oleh karena itu, sangatlah masuk akal proposisi Pratikno, bahwa dalam jangka panjang desentrailsasi belum tentu menjadi pilihan final. Karena tujuan penataan daerah tidak bisa ditetapkan secara sepihak. Siapapun pelakunya, dan apapun yang hendak diwujudkan, proses penataan daerah bisa difahami dan dikaji sebagai proses transformasi kelembagaan (Institusional Tranformation) yang terjadi dalam ruang dan waktu tertentu.
\end{abstract}

Kata Kunci : Teritorial Reform, Desain Pemerintahan, dan Kepentingan Daerah

\section{A. Pendahuluan}

Keseriusan dalam berotonomi daerah ditandai oleh peran vital strategis eksponeneksponen lokal untuk menjadi perancang dalam skala Indonesia. Teritorial reform, apalagi untuk negeri seluas Indonesia yang eksponen-eksponennya ingin berotonomi, mensyaratkan adanya kemampuan untuk melakukan proses collective designing. Yang diperlukan lebih dari sekedar menggalang kesepakatan dan kesefahaman (shared vision). Tanpa memenuhi persyaratan itu, yang dikhawatirkan oleh Orde Baru akan terwujud. Pemerintah Orde Baru punya alasan untuk tidak memberi otonomi pada masa pemerintahannya. Banyak daerah yang memilih otonom untuk tidak melakukan apa-apa. Kealphaan mengembangkan kapasitas itu, akan menggoda penganut faham sentralisme akan merebut kembali kendali perubahan.

Terlepas dan pedasnya kritik yang bisa kita alamatkan kepada pemerintah Orde Baru, harus diakui arti pentingnya kita mendisain Indonesia yang sebagai realitas translokal. Cukup alasan bagi Pemerintah Orde Baru untuk tidak memberikan otonomi kepada daerah ketika daerah hanya sanggup berfikir ke dalam (Inward looking) dan bahkan autarkhis (hanya mementingkan daerahnya sendiri). Kalau 'otonomi daerah' disepkati sebagai kata kunci dalam pengembangan daerah, harus dipastikan daerah tidak berperilaku seperti katak dalam tempurung. Skema baru dalam pengembangan daerah, yakni skema yang memberikan otonomi kepada daerah, hanya bisa bermuara pada pengembangan Indonesia sebagai realitas translokal kalau setiap eksponen lokal mengembangkan kapasitas ganda berfikir dan bekerja (inward looking maupun outward looking).

Dengan berbekal framework desentralisasi, bukan saja pemerintah pusat secara resmi memperluas otonomi pemerintahan lokal, eksponen lokal memiliki ruang yang sangat lebar untuk menjadi arsitek penataan daerah. Aturan hukum yang berlaku dari 
waktu ke waktu sebetulnya sama, bahwa daerah bisa dimekarkan dan bisa juga digabungkan. Hanya saja, runtuhnya legitimasi politik pemerintah pusat dalam melakukan penataan daerah di masa lalu telah mendelegitimasi peran pemerintah dalam penataan daerah di masa sekarang ini. Pemenitah Pusat, baik eksponen eksekutif utamanya Departemen Dalam Negeri maupun legislatif (Dewan Perwakilan Rakyat) begitu mudah meluluskan usulan pemekaran unit pemerintahan baru.

Syaratnya, sekedar memenuhi persyaratan-persyaratan yang diminta oleh Undangundang dan Peraturan Pemerintah yang mengatur hal tersebut. Begitu mudah bagi suatu daerah untuk mendapatkan surat ijin mendirikan daerah baru. Pemerintah sama sekali tidak memiliki disain atau framework yang jelas dalam mengendalikan proses pemekaran wilayah. Dalam koteks ini kita meyaksikan gejala pembiaran sebagai suatu strategi perumusan kebijakan. Kecenderungan seperti ini, oleh Abdul Gaffar Karim, disebabkan oleh desentralisasi di Indonesia adalah ibarat sebuah bangunan bersifat mudah goyah karena dibangun di atas fondasi yang bermasalah.

Oleh karena itu, kiranya sedini mungkin pemerintahan daerah perlu melakukan pembenahan terhadap keseluruhan sumber daya yang dimiliki terutama sumber daya manusianya. Sumber daya ini selayaknya dapat memberikan konstribusi yang berarti dalam upaya pencapaian tujuan organisasi pemerintahan daerahnya. Terkait dengan sumber daya manusia, terdapat pengertian manajemen sumber daya manusia yang diinformasikan oleh para ahli merupakan suatu perencanaan, pengoperasian, pengarahan dan pengawasan atas pengadaan dan pemutusan hubungan kerja dengan maksud untuk mencapai tujuan organisasi secara terpadu. Berdasarkan defenisi diatas ternyata manajemen sumber daya manusia mulai dan proses perencanaan sangat kompleks sifatnya.

Menurut Barry (1994) serta John dan Paulie (1998), perencanaan sumber daya manusia sebagai suatu cara untuk mencoba menetapkan keperluan tenaga kerja untuk suatu periode tertentu baik secara kuantitas maupun kualitas dengan cara-cara tertentu. Selain itu, analisis pekerjaan merupakan suatu proses untuk menentukan isi suatu pekerjaan sehingga dapat dijelaskan kepada orang lain untuk tujuan manajemen. Analisis pekerjaan inilah yang nantinya berwujud diskripsi pekerjaan (job discriptions).

Hal lain yang perlu di manage adalah rekruitment dan seleksi yang orientasi kualitas SDM. Selain itu, produktifitas, prestasi kerja atau kinerja aparatur juga merupakan kajian manajemen sumber daya manusia yang dimaksudkan untuk membandingkan antara hasil yang dicapai (output) dengan keseluruhan sumber daya yang digunakan (input).

Pencapaian target yang berhubungan dengan kerja yang maksimal yaitu pencapaian target yang berkaitan dengan kualitas, kuantitas dan waktu disebut "Efektifitas". Sedangkan pencapaian target yang kedua yaitu efesiensi yang berkaitan dengan upaya membandingkan input dengann realisasi penggunaannya atau bagaimana pekerjaan itu dilaksanakan.

Kompleksitas fungsi manajemen personalia, mengharuskan untuk menetapkan program-program pengembangan yang disusun secara cermat dan didasarkan pada metode-metode ilmiah serta berpedoman pada keterampilan yang dibutuhkan organisasi saat ini maupun untuk masa depan. Pengembangan adalah suatu proses bagaimana membuat seorang individu atau kelompok menjadi berkembang atau memiliki kekuatan, kemampuan dan memiliki kemandirian dalam mengelola suatu kebutuhan atau menghadapi permasalahan tertentu.

Selanjutnya makna yang terkandung dalam konsep sumber daya manusia tak terlepas dengan pembahasan mengenal manajemen personalia, karena pada dasarnya menajemen sumberdaya manusia adalah suatu perencanaan, pengorganisasian, 
pengarahan dan pengawasan dan pengadaan, pengembangan, pemberian kompensasi dan pemeliharaan tenaga kerja dengan maksud untuk membantu mencapai tujuan-tujuan organisasi (Schuler,1999:139).

Pada dasarnya pengembangan sumber daya manusia menurut pendapat Handoko (1994:103) memiliki dua tujuan utama, yaitu meliputi; pertama untuk menutup "gap' antara kecakapan atau kemampuan karyawan dengan permintaan jabatan; kedua meningkatkan efisiensi dan efektivitas kerja karyawan dalam mencapai sasaran-sasaran kerja yang ditetapkan.

Sedangkan Hasibuan (1997:75) mengemukakan bahwa tujuan yang diharapkan dan pengembangan sumber daya manusia adalah untuk meningkatkan kemampuan teknis, teontis, konseptual dan moral karyawan supaya prestasi kerjanya baik dan mencapai hasil yang optimal. Pengembangan sumber daya manusia sangat penting kaitanya dengan upaya menghilangkan kesenjangan antara kemampuan kerja dengan tuntutan tugas sekaligus mampu menghadapi tugas-tugas sekarang maupun dimasa yang akan datang.

Siagian (1997:183-184) memberikan tujuh kriteria manfaat yang dapat dipetik dan adanya pengembangan sumber daya manusia, antara lain meliputi :

1. Peningkatan produktivitas kerja organsiasi.

2. Terwujudnya hubungan yang serasi antara atasan dan bawahan

3. Terjadinya proses pengambilan keputusan yang lebih cepat dan tepat

4. Meningkatkan semangat kerja seluruh tenaga kerja dalam organisasi

5. Mendorong sikap keterbukaan manajemen

6. Memperlancar jalannya komunikasi yang efektif

7. Penyelesaian konflik secara fungsional.

Kriteria manfaat pengembangan sumber daya manusia sebagaimana disebutkan di atas menunjukkan betapa pentingnya eksistensi sumber daya manusia dalam pencapaian tujuan organisasi. Bagi organisasi pemerintah, maka arah kebijakan pengembangan sumber daya aparatur lebih ditujukan dalam rangka menciptakan sosok aparatur yang profesional.

Kebijakan pengembangan sumber daya aparatur yang demikian menurut Rasyid (1998:41) mencerminkan dua aspek utama, yakni : Pertama aspek keahilan, yaitu berupa kebijakan penyiapan sumber daya aparatur yang profesional, yang benar-benar dilandasi pada hasil kajian mengenai adanya potensi, kondisi dan kebutuhan nyata pemerintah. Kedua aspek perilaku, yakni pengaturan mengenai penyiapan sumber daya aparatur yang profesional perlu semakin diarahkan pada internalisasi prinsip-prinsip moral dan etika aparatur yang menjadi laridasan terbangunnya akuntabilitas.

Dengan kata lain, Manajemen sumber daya manusia juga menyangkut desain dan imptementasi sistem perencanaan, penyusunan karyawan, pengembangan karyawan, pengelolaan karier, evaluasi kinerja, kompensasi karyawan dan hubungan ketenagakerjaan yang baik. Manajemen sumber daya manusia melibatkan semua keputusan dan praktek manajemen yang mempengaruhi secara langsung sumber daya manusianya.

Mencermati hal tersebut kiranya perlu diperhatikan kebutuhan pemerintah akan tenaga-tenaga spesialis yang memiliki keterampilan dalam pelaksanaan fungsi-fungsi teknis maupun generalis, yaitu menjamin proses penyelenggaraan pemerintah agar benarbenar bergerak sejalan dengan aspirasi masyarakat dan tidak menyimpang dari prinsippninsip etika birokrasi, aturan hukum maupun konstitusi negara.

Dan berbagai pendapat ahli tersebut, pada dasarnya prinsip pengembangan sumber daya manusia menurut Soeprapto (2000:48) tidak jauh berbeda dengan harapan atas atribut-atribut seperti : 
1. Memiliki keterampilan dan keahlian teoritis ilmiah tertentu sesuai dengan bidang pekerjaan yang akan digelutinya.

2. Harus mampu menyumbangkan ilmu dan tenaga secara optimal untuk kelancaran usaha tempat kerjanya.

3. Harus dapat mendorong peningkatan produktivitas yang berkelanjutan.

4. Memiliki sikap untuk terus menerus untuk memperbaiki dan meningkatkan keahlian dan keterampilannya.

5. Disiplin dan patuh pada aturan main profesi dan tempat kerjanya.

6. Memihki kesiapan untuk berubah atau melakukan penyesuaian terhadap perubahanperubahan yang berlangsung atau bahkan menciptakan perubahan.

Karena itu, kiranya tidak perlu lagi kita bertanya tentang pentingkah sumberdaya yang dimiliki termasuk halnya sumber daya manusianya untuk dioptimalisasikan dalam era otonomi daerah? Kiranya hakikat dan jawaban tersebut telah diketahui bersama bahwa secara politik, tujuan pemberian otonomi kepada daerah adalah untuk mendemokratiskan penyelenggaraan pemerintahan di daerah. Hakekatnya adalah bagaimana mengupayakan partisipasi aktif seluruh masyarakat daerah dalam merumuskan kebijakan public bagi pemenuhan kebutuhan mereka sendiri, maupun dalam mendukung kepentingan dan kebijakan pemerintahan nasional. Namun perlu kita semua sadari bahwa dalam era otonomi mi, keseluruhan sumberdaya yang dimiliki terutama sumberdaya manusianya perlu dimenej sedemikian rupa sehinga lahir manusia-manusia yang professional dalam bidangnya dan otonomi daerah yang selama ini hanya menjadi retorika pemerintah pusat sebelumnya tidak dilanjutkan pada pemerintahan sekarang yang pembentukannya melalui mekanisme pemilihan langsung atau demokrasi langsung yang sangat mahal pembiayaannya.

\section{B. Kajian Teoritik}

Terlebih dulu perlu dicatat bahwa sejak awal 1990-an telah berkembang berbagai wacana diantara para pemerhati pemerintahan tentang desentralisasi pemerintahan di Indonesia. Konsep otonomi yang tertuang dalam UU No.5/1974 mendapat sorotan dan kajian kritis. Ada dua pendapat yang menampil dalam diskusi-diskusi itu: Pertama, bahwa UU No.5/ 1974 masih relevan, hanya belum dilaksanakan secara konsisten. Pendapat mi kemudian mendorong lahirnya kebijakan pemerintah berupa proyek percontohan otonomi di satu daerah tingkat II untuk masing-masing Provinsi. Kedua, bahwa UU No. 5/1974 sudah harus diganti sama sekali. Sistem yang sarat dengan nuansa sentralistik itu, yang selama puluhan tahun kita praktekkan, telah membawa berbagai akibat buruk. Sistem ini dinilai telah menghambat proses demokratisasi pemerintahan.

Pendekatan sentralistik yang dipakai seringkali dilandaskan kepada argumentasi seolah-olah ia merupakan konsekuensi dan sistem negara kasatuan. Padahal argumen ini tidak memiliki dasar yang kuat, karena negara kesatuan RI yang dikonsepsikan oleh UUD 1945 sangat menghargai hak-hak otonom dan bahkan hak-hak daerah yang bersifat istimewa (lihat penjelasan UUD 1945).

Di samping itu, secara teoretik, dengan kebhinnekaan budaya masyarakat Indonesia, keanekaragaman kondisi geografis dan kesenjangan tingkat kesejahteraan antara satu daerah dengan yang lainnya, mestinya menyulitkan kita untuk menerapkan pendekatan yang seragam dalam proses pemerintahan daerah. Negara kesatuan sebagai sebuah komitmen politik tidak seyogianya digunakan sebagai jastifikasi bagi pendekatan yang seragam dan sentralistik itu.

Akibat dan penerapan pendekatan terpusat itu adalah semakin kuatnya tergantungan dan daerah kepada pemerintah pusat. Inilah akar dan hubungan pusat-daerah yang bersifat patronasi. Pada gllirannya, hal ini kemudian mematikan kemampuan dan 
daya kreativitas pemerintah dan masyarakat daerah. Sementara itu, beban pemerintah pusat yang terus memberat serta semakin kompleknya masalah yang dihadapi telah menyulitkannya dalam membuat kebijakan-kebijakan yang secara tepat merespon dinamika dan tantangan yang dihadapi. Gambaran dan kondisi yang dobel negatif ini bisa diamati melalui reaksi pemerintah terhadap krisis moneter regional yang terjadi sekitar Juli 1997.

Proses penataan daerah, tidak bisa difahami sekedar sebagai proses teknokratis: sekedar sebagai teknis untuk mencapai tujuan yang tidak controversial penetapannya. Sebagaimana dipaparkan secara sangat jelas oleh Cornelis Lay, penataan daerah adalah konsekuensi dan pertarungan politis, termasuk didalamnya pertarungan dalam menentukan tujuan atau arahnya. Proses yang dibahasakan sebagai 'penataan' sebetulnya sarat dengan konflik dan saling menelikung, termasuk dalam penentuan arahnya. Arah dan penataan yang secara umum disepakati dan telah benlangsung selama ini adalah desentralisasi.

Satu kecenderungan yang sangat berbahaya dalam pemerintahan desentralisasi adalah mendorong bentuk kompetisi tidak sehat atas pekerjaan dan investasi antar pemerintah daerah. "Perlombaan sampai ke dasar", dimana daerah-daerah bersaing untuk memperoleh investasi modal.

Otonomi daerah memerlukan penyerahan kewenangan yang signifikan; selain itu juga membutuhkan pengembangan dan penerapan standar minimum yang berlaku bagi seluruh daerah, dan mekanisme untuk melindungi secara efektif hak-hak mendasar seluruh bangsa Indonesia dimanapun mereka tinggal. Prof. Scott Bollens mengemukakan perspektif komparatifnya, bahwa Afrika Selatan yang telah menghadapi masalah ini secara terbuka, mengakui bahwa "komunitas miskin akan memperoleh pelayanan dengan tingkat yang lebih rendah dibanding dengan yang disediakan untuk mereka yang tinggal di daerah lebih kaya." Hanya kira-kira 55 persen dan komunitas di Afrika Selatan diduga mendapat pelayanan "penuh," dimana 25 persen diantaranya menerima tingkat investasi "menengah' dan 20 persen hanya pelayanan "dasar" Dalam hal yang sama, penyerahan kewenangan dan pemerintah pusat ke daerah seharusnya tidak mencegah pemerintah pusat untuk bekerja dengan giat mengangkat kesetaraan. Sistem otonomi daerah dimana yang kaya menjadi lebih kaya dan yang miskin menjadi lebih miskin tidak akan menghasilkan stabilitas politik atau kemajuan bangsa dimasa depan.

Beberapa daerah di Indonesia sekarang ini dapat memanfaatkan sumber-sumber daya yang tak dapat diperbaharui yang lebih bernilai dibanding sumber daya lainnya. Mereka telah menyampaikan permintaan yang dapat dimengerti atas "hak" untuk mempertahankan pendapatan dan sumber-sumber yang ada untuk mereka gunakan sendiri, seperti untuk pendidikan anak-anak, meningkatkan infrastruktur, meningkatkan kekayaan mereka. Tetapi ketika cadangan sumber daya minyak, tembaga, dan kayu habis, masihkan mereka akan memperoleh manfaat dan desentralisasi tersebut? Dan ketika anak-anak yang teah mereka didik pindah mengikuti kesempatan baru di daerah yang lebih kaya, apa yang akan terjadi dengan politik desentralisasi?

Oleh karena itu, sangatlah masuk akal proposisi Pratikno, bahwa dalam jangka panjang desentralisasi belum tentu menjadi pilihan final. Karena tujuan penataan daerah tidak bisa ditetapkan secara sepihak, maka kita menganalisis proses yang berlangsung sebagai proses istitusionalisasi tatanan politik. Siapapun pelakunya, dan apapun yang hendak diwujudkan, proses penataan daerah bisa difahami dan dikaji sebagai proses transformasi kelembagaan (institusionaf tranformation) yang terjadi dalam ruang dan waktu tertentu. Kalau usulan ini disepakati, kita bisa meminjam tawaran March and Olsen dalam menganalisis transformasi kelembagaan. Dibalik kesimpangsiuran proses politik yang berlangsung dalam penataan daerah tersebut di atas, March dan Olsen memberi kita 
pegangan sederhana bahwa perpolitikan pada bisa difahami sebagai proses pelembagaan atau pembakuan perilaku. Bagi para analis yang rnembayangkan penataan daerah sebagai proses yang bersifat actor-based, harus sadar betul bahwa tantangan dalam penataan daerah bukanlah sekedar memperjuangkan aspirasi melainjan juga menghadapi apa yang disebut sebagai persoalan-persoalan yang mereka sebut environmentally constrained Persoalan-persoalan tersebut pada gilirannya bisa terpecahkan karena adanya kapasitas belajar (learning capacity) dan institusi yang ada.

Untuk menjamin suksesnya pelaksanaan konsep otonomi daerah tersebut, sekali lagi, diperlukan komitmen yang kuat dan kepemipinan yang konsisten dan pemerintah pusat. Dari daerah juga diharapkan lahirnya pemimpin-pemimpin pemerintahan yang demokratis, DPRD yang mampu menjembatani antara tuntutan rakyat dengan kemampuan pemerintah, organisasi masyarakat/lembaga sosial masyarakat (LSM) yang terus memobilisasi dukungan terhadap kebijakan yang menguntungkan masyarakat luas, kebijakan ekonomi yang berpihak pada pembukaan lapangan kerja dan kemudahan berusaha, serta berbagai pendekatan sosial budaya yang secara terus menerus menyuburkan harmoni dan solidaritas antar warga.

Dalam konteks ini perlu disadari bahwa kebijakan desentralisasi dan otonomi daerah ini mungkin merupakan satu-satunya kebijakan pemerintah Indonesia yang paling besar peluangnya untuk sukses. Mengapa? Ia didasarkan pada suatu komitmen reformasi yang diterima secara nasional. Ia didukung oleh perangkat hukum yang jelas dengan visi yang jelas dan komitmen awal yang sangat kuat. Ia juga ditenima secara luas oleh pemerintah daerah, partai politik, organisasi-organisasi masyarakat, kaum intelektual, dan bahkan pemuka agama. Tidak ada penolakan yang serius terhadap kebijakan ini. Dukungan internasional, walaupun dengan sikap hati-hati, juga cukup luas dan signifikan. Maka, kalau pemerintah pusat sampai mengubah pikiran dan memelitir kembali arah dan kebijakan yang telah dirumuskannya sendiri itu, sulit membayangkan betapa kisruhnya suasana pemerintahan kita kelak.

Oleh karena itu, dan berbagai argument kehawatiran para pakar tentang nasib baik buruknya pemerintahan daerah dengan semangat otonomi daerahnya, kiranya tidak berlebihan bila ditegaskan bahwa semuanya ini diperlukan sumberdaya manusianya yang baik, jujur dan berkomitmen untuk menyelenggarakan pemerintahan ini demi kepentingan seluruh manusia baik di daerah maupun negara secara keseluruhan.

\section{Kesimpulan}

Secara umum makna yang dapat ditarik dan hash penulisan ini adalah

- Manajemen sumber daya manusia juga menyangkut desain dan implementasi sistem perencanaan, penempatan, pengembangan, pengelolaan karier, evauasi kinenja, kompensasi dan hubungan ketenagakerjaan yang baik. Manajemen sumber daya manusia melibatkan semua keputusan dan praktek manajemen yang mempengaruhi secara langsung sumber daya manusianya

- Kebijakan desentralisasi yang melahirkan otonomi daerah adalah salah satu bentuk implementasi dan kebijakan demokratisasi. Dalam konteks administrasi pemerintahan, demokratisasi memang bergandengan tangan dengan desentralisasi. Artinya tidak ada demokratisasi pemerintahan tanpa desentralisasi.

- Otonomi daerah dalam konteks ekonomi bermakna sebagai penluasan kesempatan bagi masyarakat dan pemerintah daerah untuk mengejar kesejahteraan dan memajukan dirinya. Ini akan secara signifikan mengurangi beban pemerintah pusat dan pada saat yang sama intelektual, dan bahkan pemuka agama. Tidak ada penolakan yang serius terhadap kebijakan ini. Dukungan internasional, walaupun dengan sikap hati-hati, juga cukup luas dan signifikan. Maka, kalau pemerintah pusat sampai 
mengubah pikiran dan memelitir kembali arah dan kebijakan yang telah dirumuskannya sendiri itu, sulit membayangkan betapa kisruhnya suasana pemerintahan kita kelak.

- Oleh karena itu, dan berbagai argument kehawatiran para pakar tentang nasib baik buruknya pemerintahan daerah dengan semangat otonomi daerahnya, kiranya tidak benlebihan bila ditegaskan bahwa semuanya ini diperlukan sumberdaya manusianya yang baik, jujur dan berkomitmen untuk menyelenggarakan pemerintahan ini demi kepentingan seluruh manusia baik di daerah mapun negra secara keseluruhan.

\section{DAFTAR PUSTAKA}

Abdul Gaffar Karim et. Al (ed.); Kompleksitas Persoalan Otonomi Daerah di Indonesia, diterbitkan Pustaka Pelajar untuk Jurusan Ilmu Pemerintahan Fakultas Ilmu Sosial dan Ilmu Politik, Universitas Gadjah Mada, 2003.

Comelis Lay dan Purwo Santoso (eds.), Perjuangan Menuju Puncak: Kajian Akademik Rencana Pembentukan Kabupaten Puncak, Pemekaran Kabupaten Puncak Jaya Provinsi Papua Kerja Sama antara Program Pascasarjana Ilmu Politik, Konsentrasi Politik Lokal dan Otonomi Daerah, Universitas Gadjah Mada, 'Yogyakarta, dengan Pemerintah Kabupaten Puncak Jaya, Provinsi Papua, 2006.

Edward Schneier, 2001, Makalah Konfrensi, Desentralisasi dan Otonomi Daerah, Oktober, Jakarta

M. Ryaas Rasyid, 2001, Makalah Konfrensi, Memperkuat Otonomi Daerah, Mendorong Demokrasi, Oktober, Jakarta

Pratikno, "Desentralisasi, Pilihan Yang Tidak Pernah Final", dalam Abdul Gaffar Karim et.Al, op. cit. halaman 33-56.

Purwo Santoso, Merajut Indonesia Dalam Sinergi Kedaerahan, Makalah ini disampaikan pada Seminar Internasional ke-8 "Dinamika Politik Lokal di Indonesia: Penataan Daerah (Territorial Reform) dan Dinamikanya", yang diselenggarakan oleh Yayasan Percik, Salatiga - Jawa Tengah, pada tanggal 17- 20 Juli 2007 